\title{
X. SZÁZADI HONFOGLALÁS KORI TEMETŐRÉSZLET VEJTÉN (TEMES MEGYE, ROMÁNIA)
}

\author{
FLORIN MENDELEȚ*-DANIELA TăNASE**-GÁLL ERVIN***
}

\begin{abstract}
A Temes megyei Vejte (Voiteni) határában 1986-ban a Temesvári Bánsági Múzeum munkatársai hét honfoglalás kori sírt tártak fel, amelyek bronzkori település objektumait vágták át. A X. századi sírok a Temesköz honfoglalás kori betelepitéséröl tanúskodnak.
\end{abstract}

A nyolcvanas évek közepén a Temesköz délnyugati részéhez tartozó vejtei vasútállomástól ${ }^{1} 4,5$ km-re késő-bronzkori temetó és bronzkori telep maradványai kerültek elő (1. kép). A feltárást 1986 őszén kezdte meg a Temesvári Bánsági Múzeum, Florin Mendeleț és Alexandru Rădulescu vezetésével. Az I. kutatóárokban $(20 \times 1 \mathrm{~m})$ hét honfoglalás kori sír került elő, amelyek átvágták a bronzkori település objektumait (2. kép).

\section{A temető helyzete}

Topográfiai szempontból a vejtei bronzkori és honfoglalás kori temetók sírjait két természetes hordalék-lerakódásos kiemelkedésébe ásták, amelyeket egy kisebb völgy választ el egymástól. A honfoglalás kori sírokat a bronzkori tellbe ásták. A vízjárta Alföldön sok esetben találkozunk hasonló helyzettel. ${ }^{2}$

A sírok egy nagyobb sírszámú temetőhöz tartozhattak. Sajnos e fontos régészeti feltárás anyagi okokból nem folytatódhatott, és hasonló okok-

* Florin Mendeleț, a Román Trakológiai Intézet Bánsági részlegének elnöke, Temesvár, Románia.

** Daniela Tănase, a Bánsági Múzeum muzeológusa, Temesvár, Románia.

*** Gáll Ervin, ösztöndíjas, ELTE Bölcsészettudományi Kar, Régészettudományi Intézet, Budapest.

1 1986-ban a vejtei Âllami Mezőgazdasági Üzemhez (románul: IAS) tartozó területről régi temetkezőhely előkerülését jelezték az agyagkitermeléssel foglalkozó vejtei lakosok. A telekkönyvi kataszter alapján (amelyet akkor nem vettek figyelembe), a temető Csák (Ciacova) falu határában fekszik, amint ez az 1. képen látható.

2 Ilyen temetkezőhelyeket a Kárpát-medence területén ismerünk. Romániában: Nagyszentmiklós-Bukovapuszta, Gyulavarsánd-Laposhalom, Szalacs, Perjámos-Sánchalom, Hodony, Magyarországon: Hencida, Szlovákiában: Zemplén. ból nem került sor az antropológiai vizsgálatokra sem. ${ }^{3}$

\section{A sírok leírása}

1. sír (2. kép)

M: $70 \mathrm{~cm}$. T: ÉNy-DK. A csontváz neme ismeretlen. Karcsontok nyújtott helyzetben.

Melléklet nélkül.

2. sír (2. kép)

M: $70 \mathrm{~cm}$. T: Ny-K. A csontváz neme ismeretlen. Karcsontok nyújtott helyzetben.

Melléklet nélkül.

3. sír (2-5. kép)

Férfisír. H: 215 cm, sz: 80 cm, m: 80 cm. T: Ny-K. A csontváz neme ismeretlen. Jó megtartású, karcsontok nyújtott helyzetben.

Mellékletek: tegez részei: a bal kézcsontoktól a bal láb fejéig húzódnak a tegez oldalmerevítő vaspálcái, 11 db (4. kép 7-17). Vas nyílcsúcs, 2 db (3. kép 1-2), vaslemez szíjelosztó, a tegez részei között (4. kép 4). A tegez szájnyílása körül került elő a négyszög alakú, domborított vaslemez, felerősítésre szolgáló szegekkel (4. kép 5). Íj markolat és végcsontjai a bal lábfej környékén, $5 \mathrm{db}$ (3. kép 3). Egyik végén az irdalás nyomai jól látszanak. A bal lábfej környékén $2 \mathrm{db}$ vas nyílcsúcs. A jobb láb tájékán ellipszis és négyzet alakú vascsatok (5. kép 1). Körte alakú vaskengyel (5. kép 5) ugyanott. A kengyel párja a bal lábszárcsont alatt volt (5. kép 4). Vaszabla, erősen korrodált állapotban a lábfejek környékén (5. kép 3 a sír betöltésében). Vascsat (-).

4. sír (2. kép)

Nói sír. M: $80 \mathrm{~cm}$. T: Ny-K. A koponya elmozdult.

Mellékletek: Hajtű töredéke bronz huzalból, a koponyánál (6. kép 1). A koponya mellett nyitott ezüst hajkarikák (6. kép 2-3). Öntött bronz karperec, rombusz keresztmetszetú, a bal alkarcsonton (6. kép 6). A jobb kéz egyik

3 E temetórész a szakirodalomban már régóta ismert: BóNA 1989; BÓNA 1996, 8. 


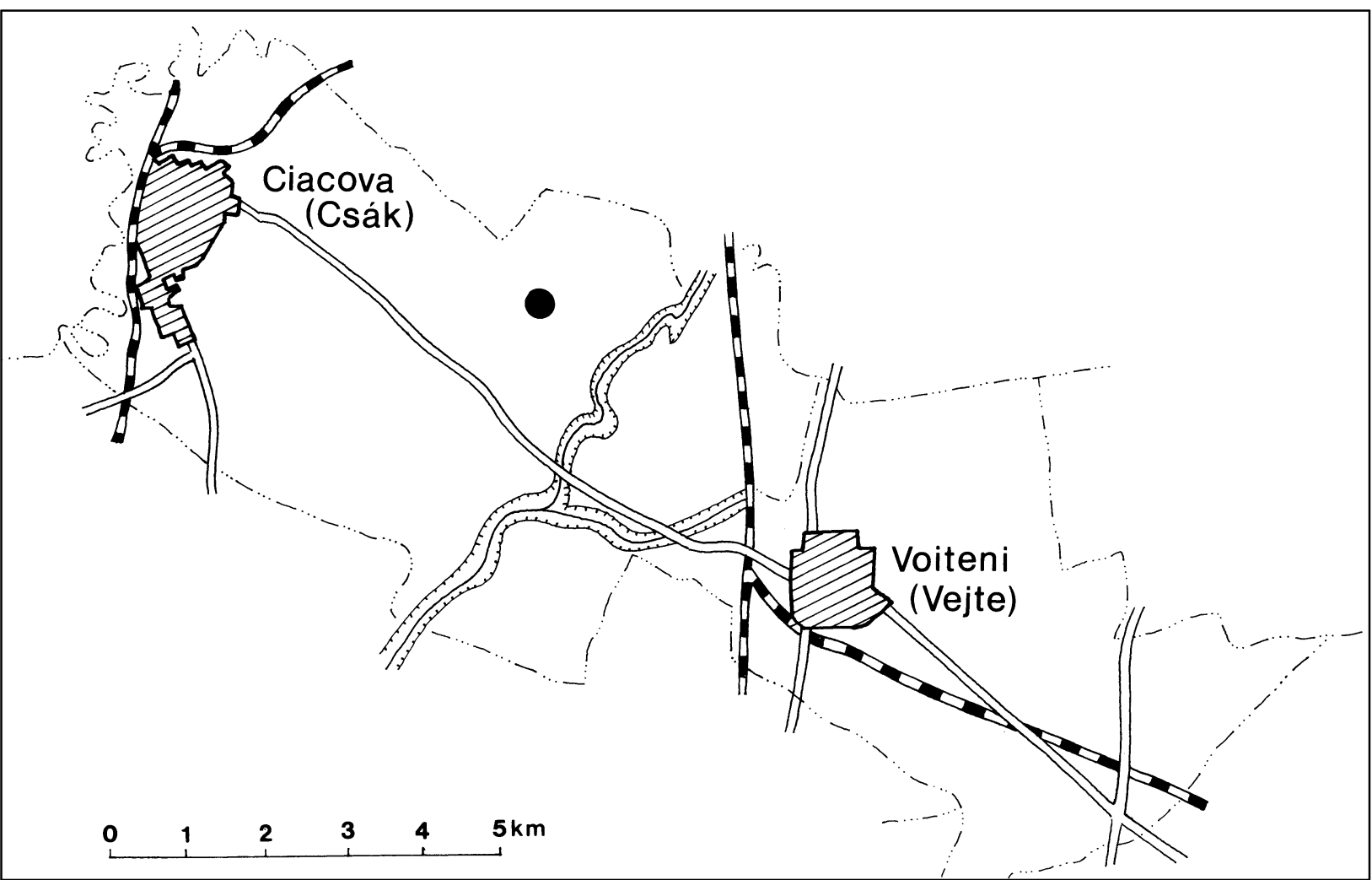

1. kép. A vejtei honfoglalás kori temető topográfiai helyzete

Abb. 1. Topographische Lage des landnamezeitlichen Gräberfeldes in Vejte (Voiteni)

ujjpercén vastag bronz huzalból készített, rombusz keresztmetszetú gyürü, végei egymásra hajlítva (6. kép 5). Kávébarna üveggyöngy, hosszában átfúrva, a medence tájékán (6. kép 4).

5. sír (2. kép)

M: $90 \mathrm{~cm}$. T: Ny-K. A csontváz neme ismeretlen.

Melléklet nélkül.

6. sír (7. kép)

Férfisír. H: $200 \mathrm{~cm}, \mathrm{~m}: 80 \mathrm{~cm}$. T: Ny-K. A jobb karcsontok nyújtva, a bal karcsontok a medencére hajlítva.

Mellékletek: vékony bronz karika, hegyes, nyitott végekkel a jobb kulcscsonton (7. kép 1).

Vas nyílcsúcs a mellkas bal oldalában (7. kép 3). Töredékes vascsat a bal térdcsont mellett (7. kép 2). Bal lábnál vas csikózabla (7. kép 4).

7. sír (2. kép)

M: $80 \mathrm{~cm}$. T: Ny-K. A sírgödör lekerekített téglalap alakú.

Sírföldben: körte alakú bronz csörgő (8. kép).

\section{Temetkezési szokások}

A vejtei temető sírjainál észlelt temetkezési szokások a honfoglaló magyarság szállásterületén megfigyeltekhez hasonlóak. A szerény mellékletek az eltemetettek társadalmi helyzetéról tanúskodnak.
A csontvázak helyzete a sírokban: a csontvázakat nyújtott helyzetben temették el. A koponyák eredeti helyzetben találhatók, csupán a 4. sír koponyája mozdult el. A karcsontok helyzete erős hasonlóságot mutat a honfoglaláskorból ismert karcsont-elhelyezési szokással. Általánosan a karokat a test mellett kinyújtják, de a 6 . sírban egyik kart a medencére hajlították. A lábcsontok kivétel nélkül nyújtott helyzetben voltak.

"Jelképes lovas temetkezések": a vejtei temetőben a honfoglalás kori lovas temetkezések egyik vállfajával, a jelképes lovas temetkezéssel találkozunk. Ez az elnevezés arra a szokásra vonatkozik, amikor csak a lószerszámokat tették a sírba. ${ }^{4}$

A 3. sírban a lószerszámok a lábak környékéről kerültek elő. A jobb lábnál a két hevedercsat, illetve a körte alakú kengyelvas. A másik kengyel a bal lábszárcsont alatt volt. Ugyancsak a lábak környékén volt az erősen korrodált vaszabla is.

A 6. sírban nem volt kengyel, a bal térd mellett töredékes vascsatot és csikózablát találtak.

4 BÁlint 1971, 107-114. 
Sok sírban megfigyelhető, hogy a zabla nem minden esetben kerül elő kengyellel együtt. Ilyen sírokat új, honfoglalás kori temetőkből ismerünk: Köröstarjánról, ${ }^{5}$ Szászvárosról ${ }^{6}$ és Temesvár-Csóka erdőről.7

E jelképes lovas temetkezések okát Bálint Csanád az anyagi szegénységben látja, ${ }^{8}$ míg Révész László ebben a szokásban sajátos hagyományt vél, ${ }^{9}$ mivel szerinte sok esetben a lószerszám jóval értékesebb a lónál. ${ }^{10} \mathrm{Az}$ viszont tagadhatatlan, hogy a lószerszámos sírokban eltemetettek általánosan szerényebb mellékletekkel rendelkeznek, mint a lóval eltemetett társaik. ${ }^{11}$

A vejtei két jelképes lovas temetkezés ismertetésével gyarapíthatjuk a hasonló temetkezéssel bíró lelőhelyek hosszú sorát. ${ }^{12}$

\section{A leletek elemzése}

A vejtei sírok leletei a honfoglalás kori anyagi kultúra jellegzetes tárgyai. A viselet tárgyi hagyatékának anyaga az ezüst és fóleg a bronz, amely általánosan a szerényebb társadalmi helyzetú közösségek viseletét díszítő tárgyainak fő anyaga. Kürti Béla szerint a bronz tárgyakat főleg a X. század második felére keltezhetjük. ${ }^{13}$

\section{Viselet}

Hajkarika: a vejtei temetőrészben a hajkarikák a nyitott és kerek átmetszetú típusa ${ }^{14}$ ismert, két változatban a 4. és 6. sírból, ezüst, ill. bronz vál-

5 Közöletlen temető (románul: Tarian, Bihar megye). Zabla a 21 , 27. és 29 . sírban volt, kengyelvas a 3, 28. és 36 . sírban. Személyes információ.

6 Zabla a 6. és 7. sírban, kengyel a 7. és 11. sírban volt (PINTERLuCA 1995, X. t. 7, XI. t.)

$7 \mathrm{Az}$ „A" sírból a csontváz lábcsontjai közeléből körte alakú vas kengyelpár ismert (RĂDULESCU-GÁLl 2001 s.a.)

8 BÁLINT 1971, 87.

9 K. K. 1996, 39.

10 Révész L. Ártánd 206. sírt idézi, amelyből ezüst veretes nyerget, ezüst lószerszámvereteket ismerünk, amely jóval értékesebb volt egy lónál. Itt azonban megjegyeznénk, hogy e gazdagabb temetkezés köznépi temetőben volt, köznépi környezetből került elő. Érdekesnek ígérkezik a gazdagabb, jelképes temetkezések lelőhelyeinek összegyújtése (MESTERHÁZY 1990, 50; K. K. 1996, 39).

11 Legjobb példa a Révész L. által feltárt Karos II. temető. E temetóben a lószerszámos sírok mellékletei jóval szegényebbek, mint a lovas síroké. Nem lehetetlen, hogy e lovas temetkezés a szegényebb társadalmi rétegek temetkezési módja volt.

12 1971-ben a lószerszámot tartalmazó sírokat felgyújtő Bálint Cs. 101 hiteles sírt ismert (BÁLINT 1971, 108).

13 KÜRTI 1978-79, 325.

14 SZŐKE 1962, 35.

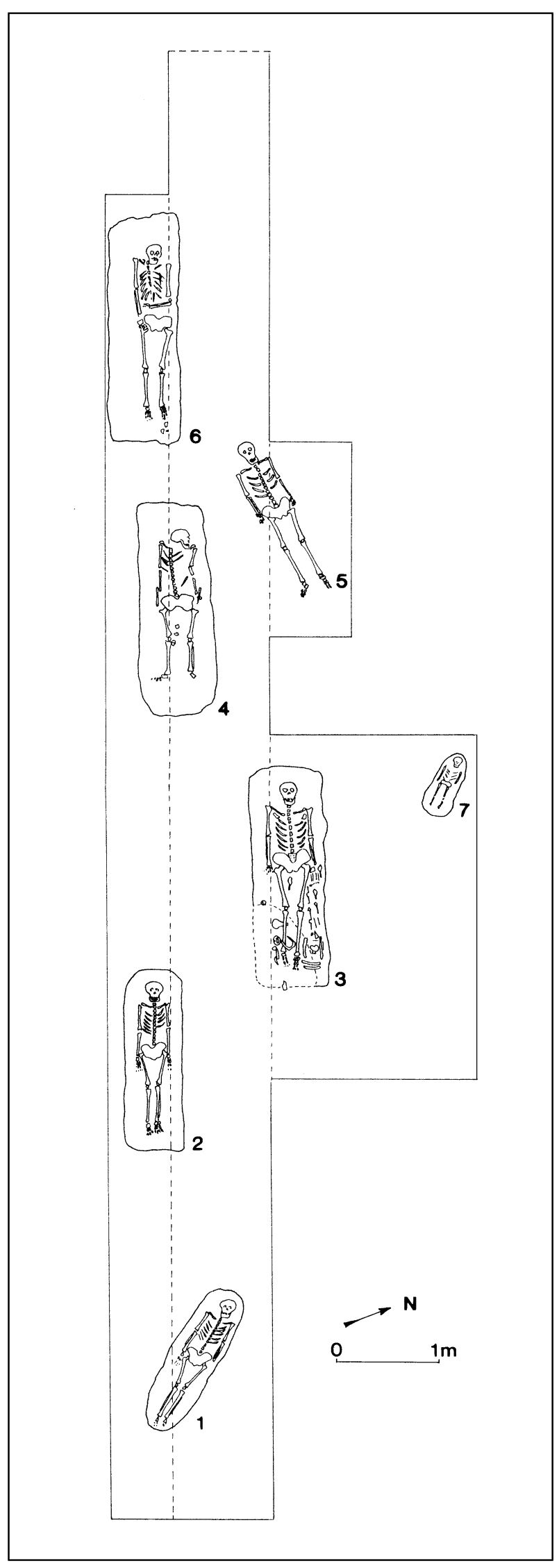

2. kép. A vejtei honfoglalás kori sírok Abb. 2. Landnahmezeitliche Gräber in Vejte (Voiteni) 


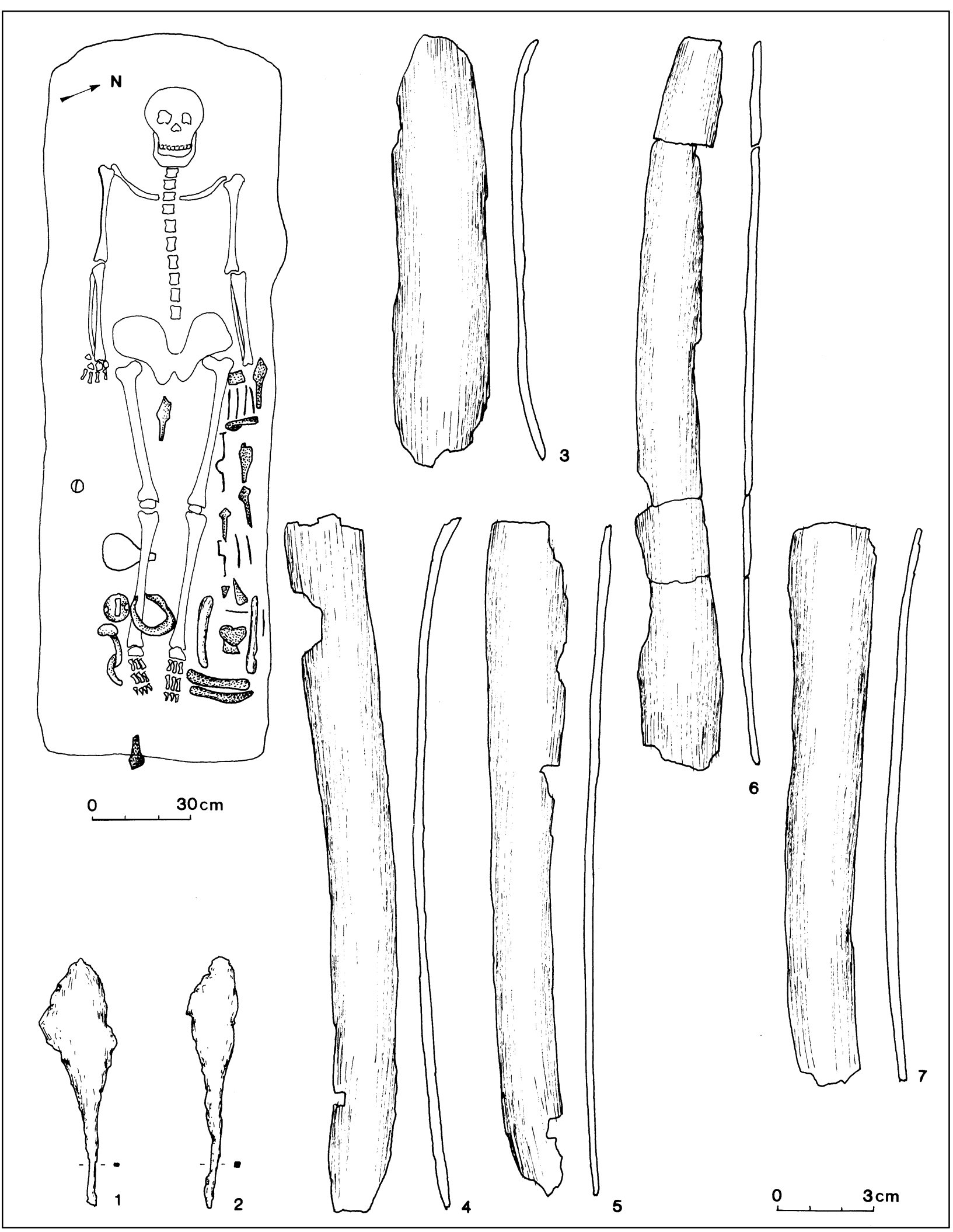

3. kép. Vejte (Voiteni) 3. sír

Abb. 3. Vejte (Voiteni) Grab 3 


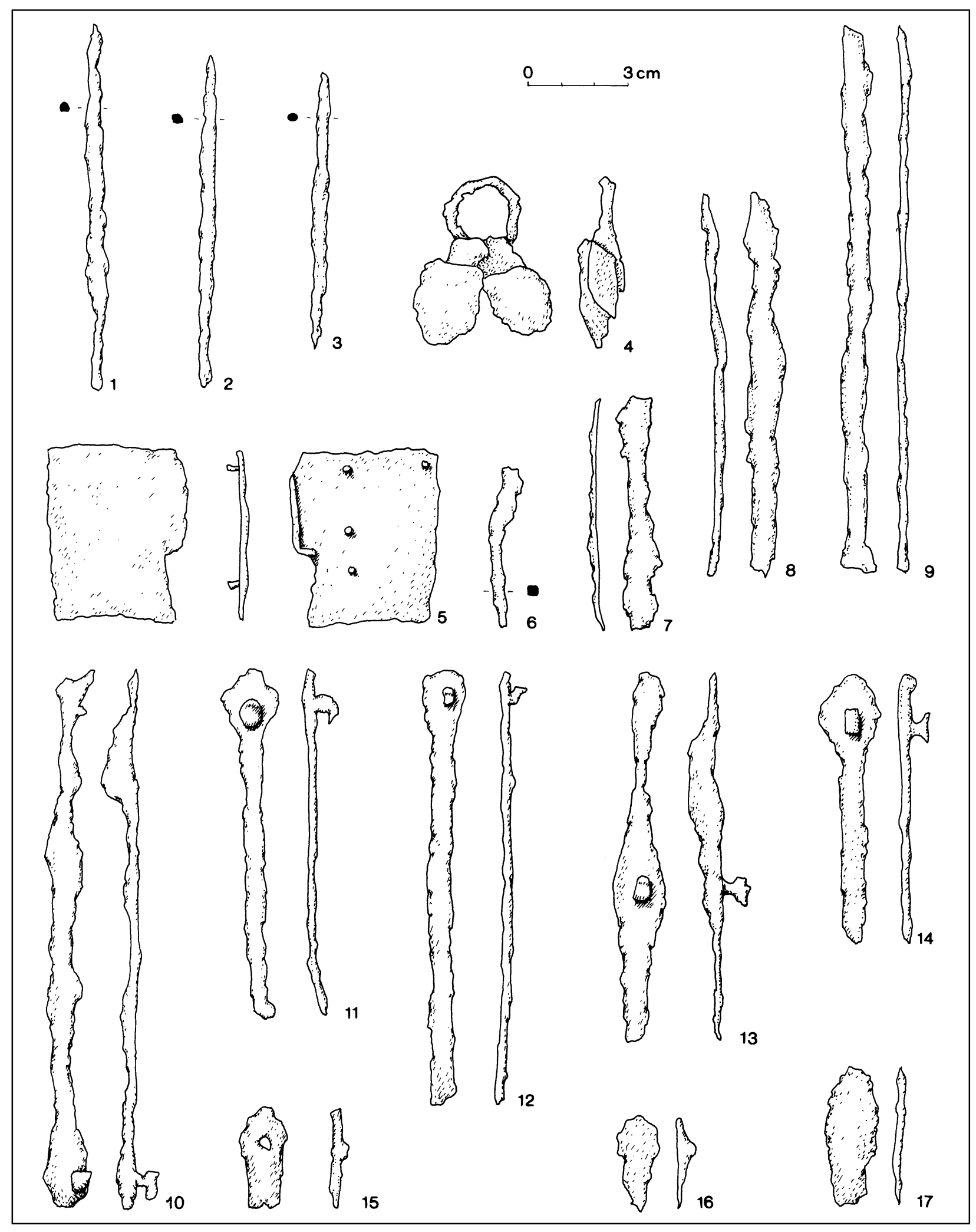

4. kép. Vejte (Voiteni) 3. sír

Abb. 4. Vejte (Voiteni) Grab 3 

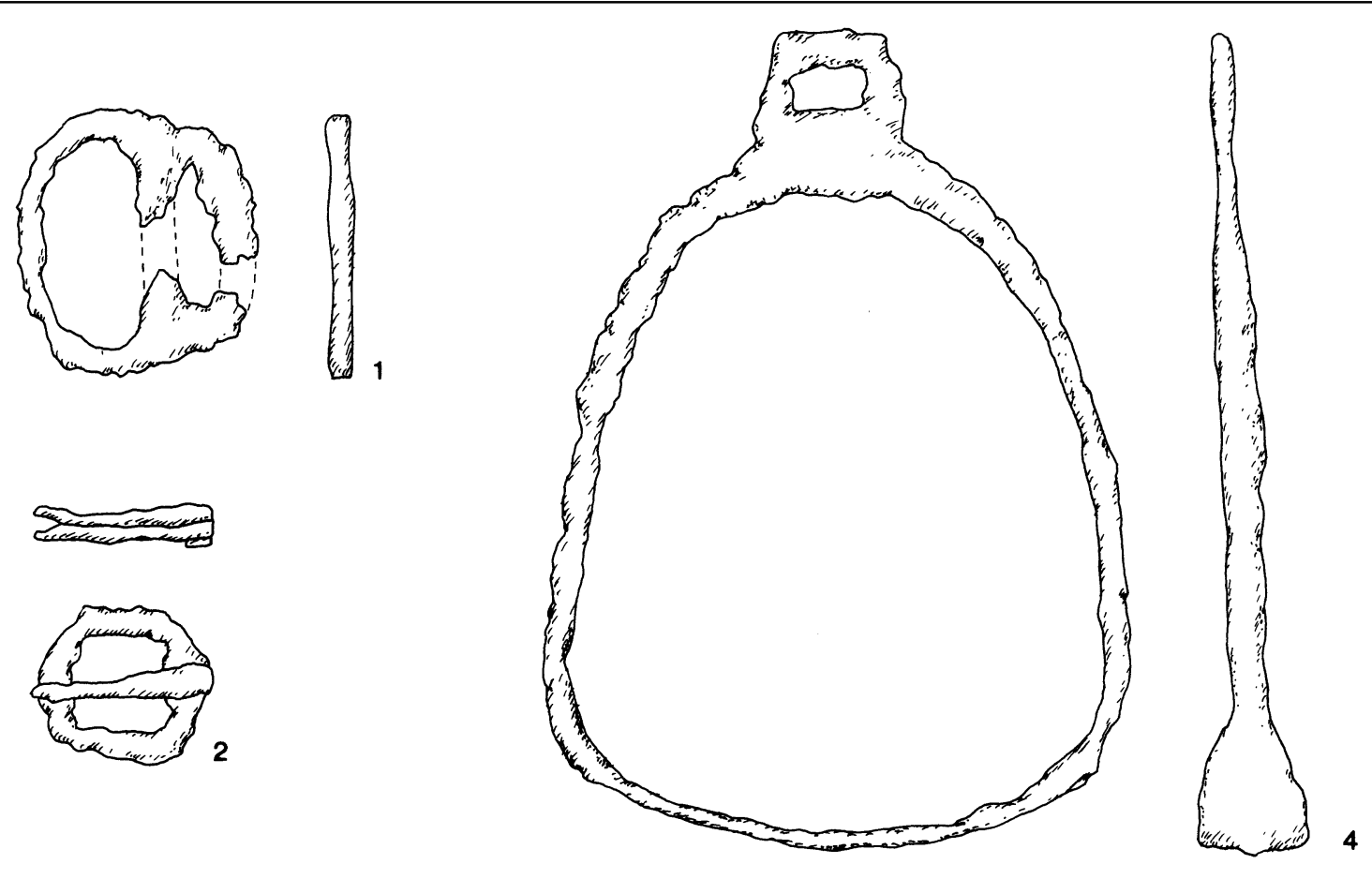

0 $3 \mathrm{~cm}$
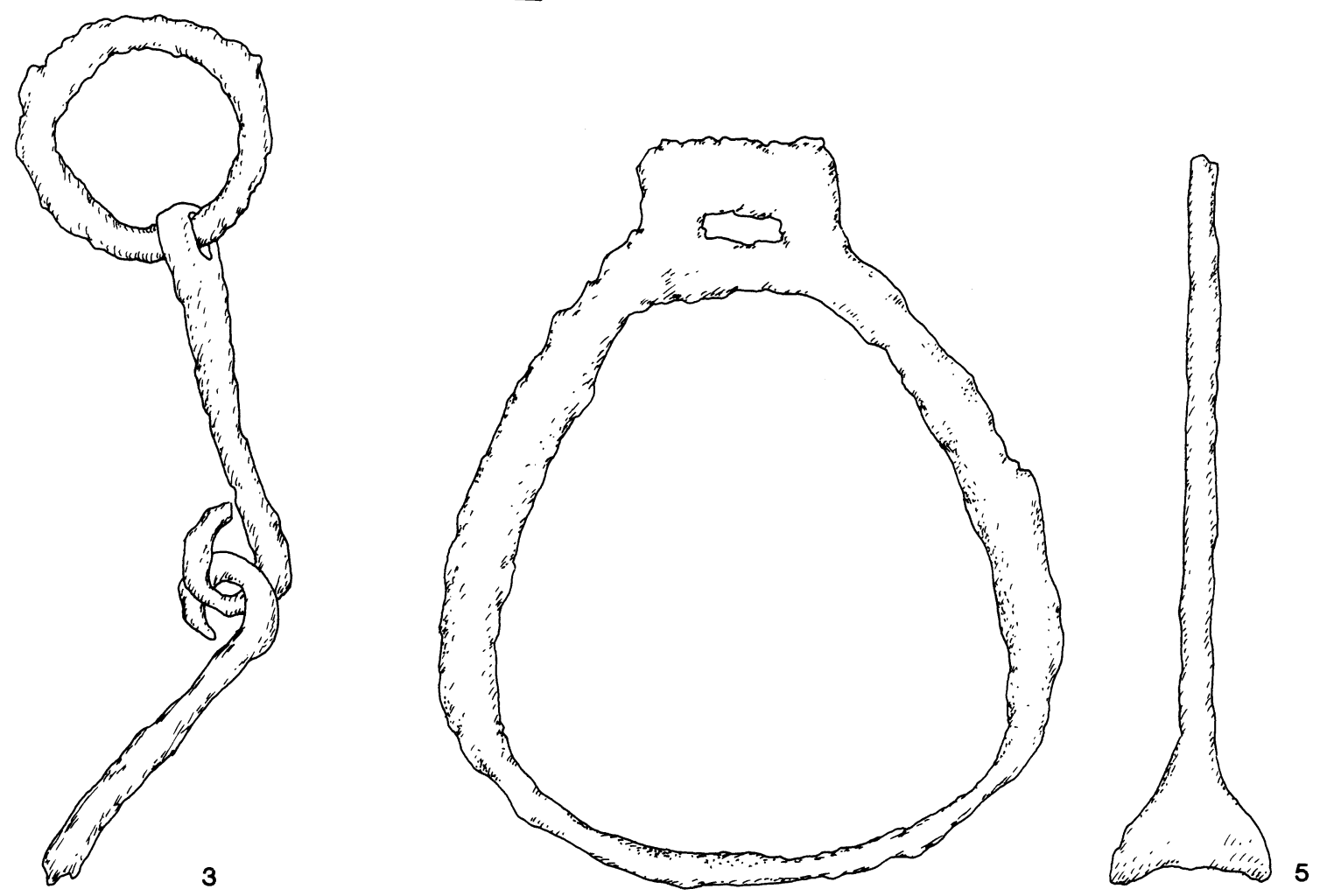

5. kép. Vejte (Voiteni) 3. sír

Abb. 5. Vejte (Voiteni) Grab 3 


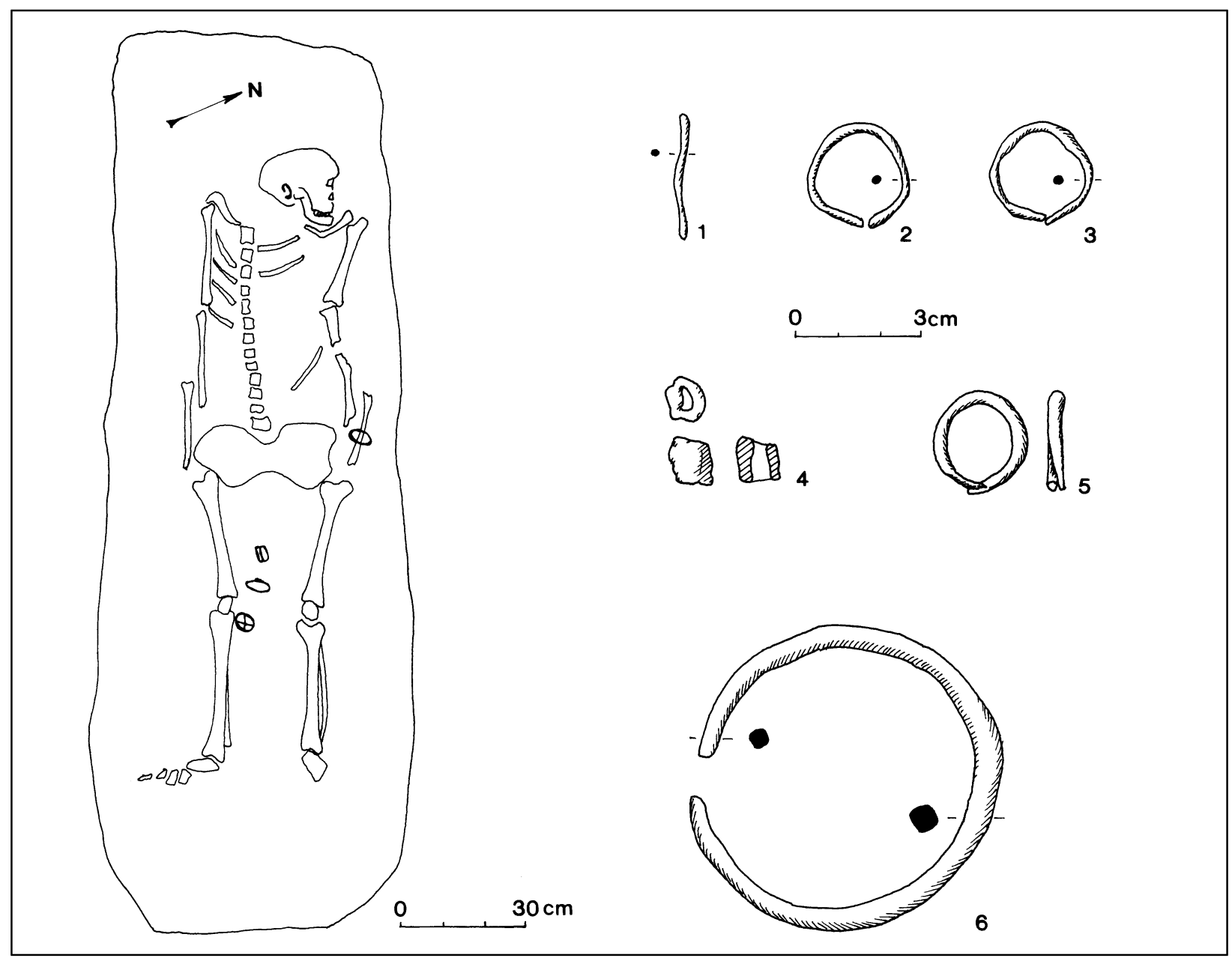

6. kép. Vejte (Voiteni) 4. sír

Abb. 6. Vejte (Voiteni) Grab 4

tozatban. A 4. sír ezüst hajkarikáinak egyik darabjánál a végeket kissé egymásra hajlították. E tárgytípus főleg a X. században volt használatban, de fellelhetó a XI. században is. A két változat időrendi helyzete még további kutatást igényel, de megfigyelt tény, hogy az Erdélyi-medencében az egymásra hajlított végú darabok bronzból készültek, és a X. század második felére keltezhetók. ${ }^{15}$

Az egyszerú hajkarikák férfi és női sírokból egyaránt előkerülnek.

Hajtü: a 4. sírban találtak egy bronz hajtú töredéket. X. századi leletekben ritkaságnak számít ez a tárgy. A történeti Bánságból csak a Temes-
vár-Csóka erdei temetóből ismerünk egy bronzból készült példányt, felületét spirális sodrással díszítették. ${ }^{16}$ A X. század második felére keltezhető.

Csörgő: körte alakú bronz csörgő a 7. sír földjéból. E tárgytípussal behatóan Szőke Béla és Kovács László foglalkozott. ${ }^{17}$ Észrevételüket, miszerint e tárgytípus gyermeksírokra jellemző, a vejtei 7. gyermeksír is igazolja. A bronz csörgó a X. századon belül nem keltezhető. ${ }^{18}$

Karperec: e csoportba a 4. sír rombusz keresztmetszetú, vágott végú karperece sorolható. A X. század második felére keltezett temetók klaszszikus lelete. A vejtei 4. sír karperecéhez hasonlóárok 7. sírja és Szászváros-Dealul Pemilor 9. sír. Az információkért Harhoiu Radu régésznek tartozunk köszönettel. PINTER-LuCA 1995, XIII. t. 10-12. 


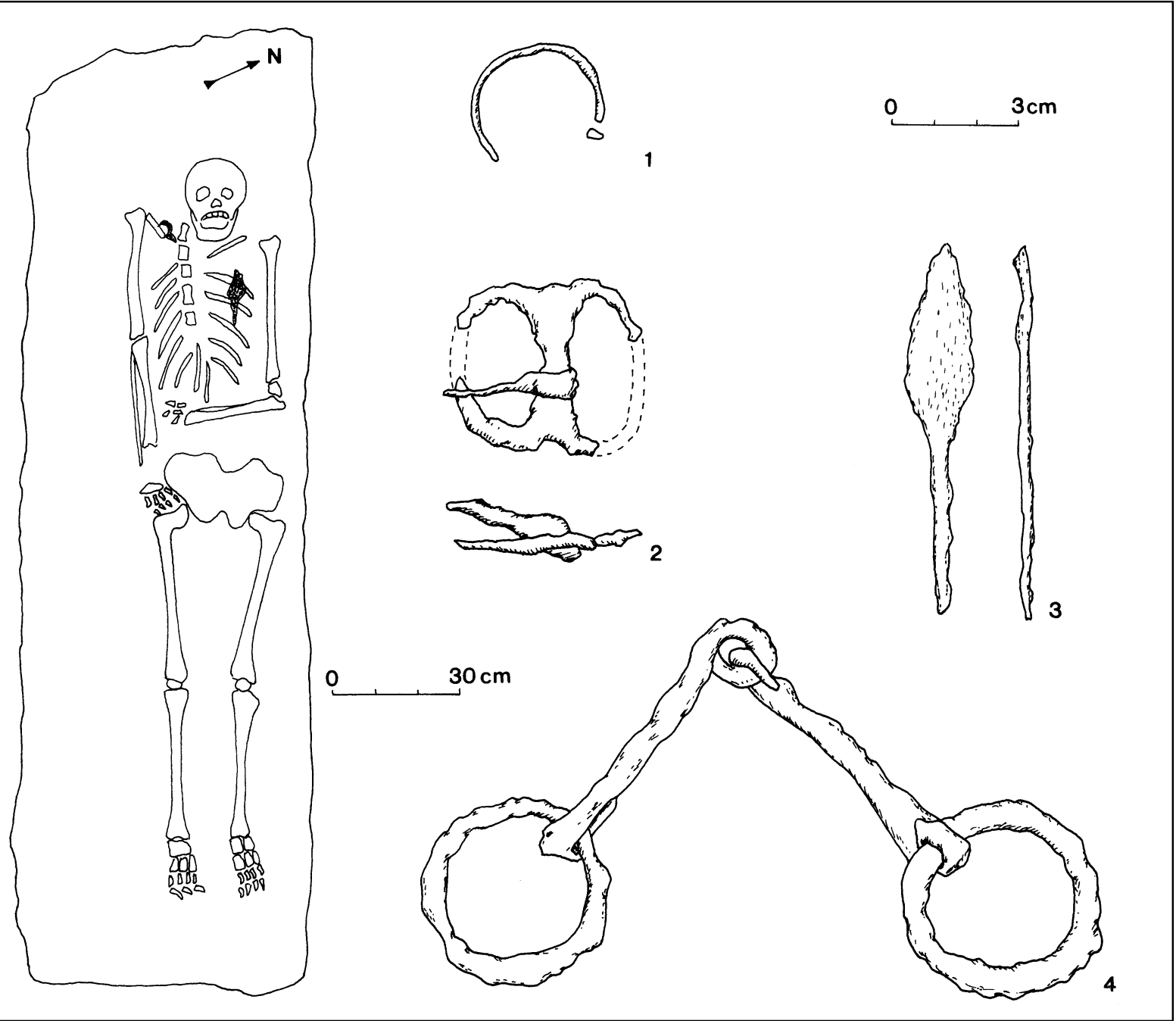

7. kép. Vejte (Voiteni) 6. sír

Abb. 7. Vejte (Voiteni) Grab 6

kat a Temesvár-Csóka erdei temető J, L és M sírjaiból ismerünk.19 A Bánság más temetőiből is jól ismert ez a karperectípus: Fönlakról (Felnac Ro.) szórványleletként. ${ }^{20}$ Eszaknyugatra, nagy részben a Tisza-Maros-Aranka találkozásánál Horgos 2. sírjából, ${ }^{21}$ Majdánról, ${ }^{22}$ Rábéról, ${ }^{23}$ valamint a kiszombori és deszki temetőkből ismerünk jó néhány rombusz átmetszetú karperectípust. Kiszombor B temető (Blaskovich F. földje) 136. sírjá-

19 RĂdUleSCU-GÁLl 2001, s.a.

20 Szórvány tárgyak: négy szálból sodrott bronz karperec; rombusz átmetszetú öntött bronz karperec, 5 db bronz huzal karperec, $3 \mathrm{db}$ ép, $2 \mathrm{db}$ töredékes, zárt bronz fejes gyưrú, a fején poncolt köröcskékkel; bronz pántgyúrü, felülete kissé domború, körte alakú, letört füllel; kör alakú kengyel (BóNA 1988, I. 208, 59, 13. kép 4-12; BÁLINT 1991, 221, 77. j.)

21 S-végú hajkarika, hengeres ezüstfóliás pasztagyöngy, huzalkarperec, fonott gyưrú, rombusz keresztmetszetú karperec (KovÁcs 1993, 59, 13. kép 4-12) ból a tárgyalt karperec egyszerú hajkarikákkal és gyöngyökkel együtt került elő. ${ }^{24} \mathrm{E}$ temető szerkezete alapján (78 X-XI. századi sír) a nagy köznépi temetôk közé sorolható. Érdekes, hogy a X. századi többi kiszombori temetőból hiányzik ez a karperectípus. ${ }^{25}$ A Kiszombortól nem messze fekvô Deszk területéról is jelentős honfoglalás kori temetőkoncentrációt ismerünk. Deszk Ambrus József Újmajor 80. sz. földjén feltárt

22 E karperec típus egyszerú karikák, barázdált díszítéses öntött bronz gyưrú és csüngős veretek társaságából ismert (FÉK 1962, No. 634)

23 Kovács László említ 3 közöletlen sírt. E karperec típus csüngős veretek, négyzet és hatszög keresztmetszetú bronz gyúrük, valamint szalaggyuurú társaságából ismert (KovÁCS 1963, 60-61)

24 FÉK 1962, No. 573

25 Kiszombor területéről a X-XI. századból 6 temetkezőhelyet ismerünk (FÉK 1962, No. 573-578) 
egyik temető sírjában fordult elő egy négyszög keresztmetszetú ezüst karperec. ${ }^{26}$ E település Nádashalmi dúlőben feltárt avar kori sírjai között honfoglalás kori sírokat is feltártak. E sírokból is ismertek rombusz átmetszetú karperecek, fegyverek Árpád-házi királyok érmeivel együtt. . $^{27}$

E tárgytípus keltezése a felsorolt lelőhelyek esetében is illeszkedik az eddigi kronológiához. Szabó János Győző szerint csak a XI. századtól használták, ${ }^{28}$ viszont más szakemberek véleménye alapján használatukat már a X. század második felétól számíthatjuk. ${ }^{29} \mathrm{E}$ keltezés támogatja a vejtei temetőrészbőll levonható időrendi következtetéseket is.

Gyürü: egymásra hajtott végü, rombusz keresztmetszetú gyûrû́ volt a 4. sírban. Ez a típus, hasonlóan a rombusz keresztmetszetû́ karperecekhez, a X. század második felében volt használatban. Szőke Béla és Johann Giesler szerint megjelenésük a XI. század elejére tehető. ${ }^{30}$

A tiszántúli délkelet-alföldi lelőhelyek közül Rábéról, Deszk D temetőből, Klárafalva B temető 36. sírjából és Temesvár-Csóka erdő J és $M$ sírjaiból ismerünk rombusz keresztmetszetú gyưrúket. ${ }^{31}$ A rábéi rombusz keresztmetszetú gyưrút Kovács László a X-XI. század fordulójára keltezi. A deszki és klárafalvi leletek a XI. században voltak használatban. A temesvári 40 síros temetőrészből hiányoznak a XI. század klasszikus leletei, a temetórész használata a $X$. század második felében történt. A rombusz keresztmetszetú és az állatfejes karperecek használatának kezdeteit a X. század második felétól keltezi Kovács László. ${ }^{32}$ A vejtei gyưrú keltezését nehezíti, hogy a szintén a 4 . sírban talált rombusz keresztmetszetú karperecen kívül a feltárt 7 sírban nincs más olyan tárgy, amely biztosan a X. század második felére lenne keltezhetó.

Gyöngy: a 4. sír medencetájon előkerült kávébarna üveggyöngye a ruhára lehetett felvarrva. A sír gyúrúje és karperece a gyöngyöt a X. század második felére keltezi.

26 FÉK 1962, No. 221.

27 FÉK 1962, No. 222.

28 SZABÓ 1978, 79, 66.

29 SZŐKE 1962, 94-95; GIESLER 1981, 120-121, Taf. 53.

SZŐKE 1962, 97; GIESLER 1981, 110, Taf. 53.

31 KovÁcs 1991/92, 60; FÉK 1962, No. 222 és No. 579, RADULESCU-GÁLL 2001 s.a.

32 KovÁcs 1994, 134, 136.

33 A közöletlen gyulafehérvári temetőben több íjas temetkezés volt: 17, 36, 3, 5, 4, 8, 13, 16, 5. sírok (több évi ásatás). A sírokban az íjcsontokon kívül jellegzetes honfogalás kori leletek

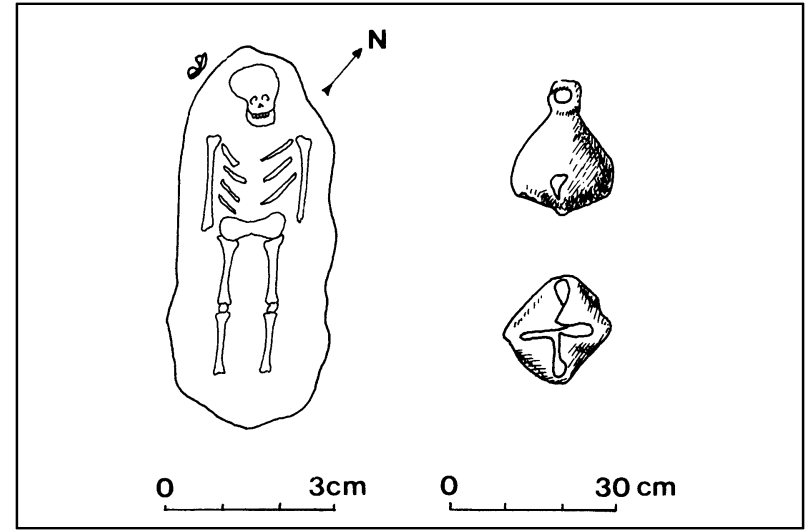

8. kép. Vejte (Voiteni) 7. sír

Abb. 8. Vejte (Voiteni) Grab 7

\section{Fegyverek}

Íj: a vejtei temetőrész 3. sírjában, a csontváz bal lábcsontjai mellól kerültek elő íjcsontok. Az íjat nyugalmi állapotban helyezték a sírba. Az íj markolatát és végeit csontlemezek erősítették. A négy íjcsont enyhén ívelt, felső negyedük kiszélesedik, egy darabon az ideg beakasztására szolgáló vájat is megfigyelhető.

Az íjcsontok a Kárpát-medencében letelepedett honfoglaló közösségek szállásterületein feltárt temetőkből jól ismertek, a Dunántúltól az Erdélyi-medencéig. ${ }^{33}$ Kelet-Alföld tiszántúli részének temetóiból is nagy számban ismertek az ijas temetkezések (Deszk-Újmajor, DeszkNádashalmi dúlő). ${ }^{34}$ A Kiszombor környéki temetókból is több íjas temetkezés ismert (B temetó $12,26,230$. és 284 . sírja). A 12 . sírban tegez is volt, a 26. sírból még pásztorkészséget is ismerünk. A 284. sír többi melléklete: hajkarika, tegez, nyílcsúcsok. ${ }^{35}$ Kiszombor C temető (Nagyhalom) 13. és 15. sírjában volt íjas temetkezés. ${ }^{36}$ Kiszombor-Kis András földjén feltárt honfoglalás kori temetó 13. és 39. sírja íjas lovas harcosé volt, ${ }^{37}$ hasonlóan íjas sír volt a Kiszombor F temető 1 . sírja is. ${ }^{38}$

kerültek elő: tegez, szablya, pásztorkészség, hajkarika. Harhoiu Radu úr szíves szóbeli közlése. Ugyancsak íjcsontok láttak napvilágot a Kolozsvár-Pata utcai temetőben is, ahol négy, íjjal eltemetett harcos sírját tárták fel. Az információért Hica Ioana régészt illeti a köszönet.

34 FÉK 1962, No. 221-222.

35 FÉK 1962, No. 573.

36 FÉK 1962, No. 574.

37 FÉK 1962, No. 575.

38 FÉK 1962, No. 576. 
Délen, a mai Szerbia északi részén Törökbecse (Novi Bečej)-Matej pusztáról (Matejski Brod) ismerünk íjas-tegezes-lovas temetkezést. ${ }^{39}$

A fent idézett ijas sírok keltezése nehézségbe ütközik, mert a a temetők közöletlenek, így nem készülhettek el a horizontál-stratigráfiai vizsgálatok. Más példák alapján azonban a X. századon belül az íjcsontos lelőhelyek pontosabban nem keltezhetők, bár zömük valószínúleg a X. század első két harmadára tehető. A felsorolt sírok esetében nem mutathatók ki olyan társmellékeletek, amelyeket a X. század második felére vagy a XI. századra kellene kelteznünk. A vejtei példányokat a X. század első felére keltezhetjük.

Tegez: maradványai a 3. sírból kerültek elő. A tegez vas merevítő pálcái és függesztői a bal kézfejtől a csontváz bal lábfejéig húzódtak. Sajnos az ásatók a tegez hosszát nem mérték le a sírban. A tegez szájnyílásának csont veretei hiányoztak, de ide tartozhat az a négyzet alakú ívelt vaslemez, amelynek felületén három lyuk van.

A tegez felszereléséhez tartozik a lemezes szijelosztó karika. A bal lábfejnél, a tegezpálcák környékéról került elő, a tegezhez tartozhatott, annak ellenére, hogy általában lófelszerelésben ismerjük. Hasonló darab van a karosi I. temető 1. és a Kolozsvár-Zápolya utcai temető 11. sírjában, mint lószerszám része. ${ }^{40} \mathrm{~A}$ vejtei darab - helyzete miatt - a tegez felfüggesztésében játszhatott szerepet.

Tegezes sírok nagy számban ismertek a tiszántúli X. századi temetőkben. A teljesség igénye nélkül említjük meg a deszki, a Kiszombor környéki temetőket, a Matejski Brodnál feltárt sírt, a Nagyszentmiklós-Bukovapuszta-i példányokat, és a nagykomlósi, ill. szakállházi leleteket. ${ }^{41}$

Temesközból a Temesvár-Csóka erdei temető $B$ és G sírjában volt tegez, ill. annak részei: függesztő veretek, függesztéshez használt karikák, merevítő pálca, amelynek felső része függesztő füllé volt alakítva. Hasonlót figyelt meg Révész László a karosi feltárásokon. ${ }^{42}$

Nyílcsúcsok: a temetőrésznek három sírjából kerültek elő nyílcsúcsok. A 3. sírban 5 nyílcsúcs volt, a 6. sírban $1 \mathrm{db}$, a csontváz bal oldalán. Ez utóbbi aligha melléklet, inkább rituális célból ke-

\footnotetext{
39 StANOJEV 1989, 64, Abb. 332-342; FÉK 1962, No. 547.

40 RÉvÉSZ 1996, 4. t. 41-43.

41 FÉK 1963-2, No. 221-226, 573-576, 647; STANOJEV 1989, 64, Abb. 333-334; BejAN-MARE 1997, 141.

42 RÉVÉSZ 1996, 173, 29. t .1-2.

43 GÁLl 2002, s.a.

44 BÁlint 1971b, 49-86; NAGY 1968, 69-100; KovÁCs 1984, 25, 25; MEGAY 1961, 100-108.

45 DIENES 1966, 229-232.
}

rülhetett a sírba, vagy halált okozó fegyverként. Ez a Kárpát-medence honfoglalás kori sírjaiban elég gyakran észlelhető jelenség. Több ilyen „rendellenes” esetet ismerünk. Az Erdélyi medencéból megemlíthető: Déva-Mikro 15, 2, 6. sír, Gyulafehérvár-str. Brandusel 7. sír, Szászváros 2. és 7. sír. Ezekben a sírokban a nyílhegyet a csontváz oldalbordái között vagy a térdcsontjában találták. ${ }^{43}$ Hasonlót figyeltek meg Eger, Szabadkígyós-Pálliget, Hajdúböszörmény és MiskolcRepülőtér temetőiben is. ${ }^{44}$

A vejtei sírok nyílcsúcsai három típusba sorolhatók: rombusz alakú nyílcsúcs (3. sír), rövid, ill. hosszú vágó élú nyílcsúcs (3. és 6. sír), páncéltörô nyílcsúcs (ritka példány, a 3. sírban volt).

E típusok használata a X. századi sírokban nem köthetô pontosabb időrendhez. A század elejétól a XI. századig használták ezeket a Kárpát-medence honfoglalás kori és kora Árpád-kori harcosai.

\section{Lószerszámok}

Kengyelek: a honfoglaló harcos réteg sírjainak nagy részében a kengyelpárok darabjainak méretei különbözőek. Dienes István megfigyelése ${ }^{45}$ érvényes a vejtei 3 . sírra is, ahol szintén felemás kengyelpárt találtak. Egyik darab keskeny négyszög alakú füle nyak nélkül csatlakozik a kengyel félkör átmetszetú száraihoz. A talpaló homorú és keskeny, bordázat nélküli. A kengyelpár másik darabja szélesebb és rövidebb. Fülét és szárait laposra kalapálták, amelyek a széles, bordázott és homorú talpalóhoz csatlakoznak.

E kengyeleket általában a X. század első két harmadára keltezik, de vannak példák a század második felében történő használatra is. ${ }^{46}$

A kelet-alföldi lelőhelyekről is nagy számban ismertek ezek a kengyeltípusok. (Pl.: AradCsálya, Fönlak, Hodony, Matejski Brod, Németszentpéter, Temesvár, Kiszombor, Deszk. ${ }^{47}$

A vejtei kengyelek a körte alakú kengyelek típusába tartoznak. A vejtei 3. sír kengyeleit feltehetően a X. század közepére keltezhetjük. A szoros időrend kialakítása a jövő kutatásának feladata.

46 Néhány példa: Öcsöd-Mogyorós: HAMPEL 1905, II. 656-657, III. Taf. 431, Szered-Mácséi dombok: TočIK 1968, XLVIII. t. 1-11.

47 Arad: DöRNER 1970, 447-449; Fönlak: kérdéses a lelet együvé tartozása: BÓNA 1988, 41. ábra, BÁLINT 1991, 221, 77. j., Hodony: Bejan-Moga 1979, 2. kép 1, Matejski Brod: Stanojev 1989, 64, Abb. 333-342, FÉK 1962, No. 647, Németszentpéter: DÖRNER 1970, 457; Temesvár: RADUlesCu-GÁll 2001 s.a.; Kiszombor, Deszk: FÉK 1962, No. 221-226, 573-578. 
Zablák: a ló irányításának meghatározóan fontos eszköze a zabla. ${ }^{48}$ A honfoglaló magyarság által használt zablák nagy többsége csikózabla, főleg az egyszerúbb harcosok sírjaiból ismertek. E tárgytípus az alföldi leletekben is nagy számban ismert.

A vejtei sírok közül a 3. sírban a lábak környékén volt egy erősen rozsdásodott zablatöredék, a 6. sírban pedig a bal láb közeléből került elő egy csikózabla, nagyméretú karikákkal. Ezt a típust a X. századon belül nehéz pontosabban keltezni.

A csikózablák a lovas temetkezések jellemző leletei, de jelenlétük a lovas sírokban nem általános.

Hevedercsatok: a nyereg rögzítésénél használt csatok a ,jelképes" lovas sírból ismertek. A 3. sírban két csat volt, egy ellipszis alakú és egy kétosztatú. A 6. sírban szintén kétosztatú csat volt. Nagyméretú, kétosztatú csatokat SzentesNagyhegyről, Tiszafüredről és SomogyvárKapuvárhegyről ismerünk. ${ }^{49}$

\section{A temetôrész belső szerkezete és idôrendje}

A vejtei 7 honfoglalás kori sír sort alkot. A 7 sír időrendjében némi időbeli különbség figyelhető meg, kissé korábbinak túnnek az 1, 2, 3. felnőtt és a 7. gyermeksír, amelyek a 3. ijas sír mellékletei alapján a X. század első felére/közepére keltezhetók.

Valamivel későbbinek túnik a 4,5, 6. sír, a 4 . női sír a X. század második felére keltezhető köznépi mellékletei alapján.

A temetô használata pontosabb keltezéséhez további feltárásra lenne szükség.

A vejtei temetőrész - leletanyaga alapján - a Tisza-Maros-Aranka-Temes-Béga fegyveres köznépi temetőivel mutat rokonságot, azok közé sorolható.

\section{A vejtei temetô régészeti és történeti környezete}

A kutatás mai állása alapján a Temesköz magyar megszállásának ideje pontosan nem rögzíthető. A nyugatra és északra fekvő területeket a régészeti adatok szerint a magyarság a X. század elején szállta meg. Korai leletek ismertek a Tisza-

\footnotetext{
48 A zablákkal negyven éve Dienes István foglalkozott behatóan. Megállapításai a mai napig érvényesek: DiENES 1966, 208-232.

49 RÉvÉSz 1988, 530.
}

Maros-Aranka által határolt területról. Sajnálatos, hogy nagyobb részt csak szórványleleteket ismerünk. ${ }^{50}$ Délkeletre is pompás honfoglalás kori sírok kerülnek elő, amelyek a X. század első felére keltezhetők. ${ }^{51}$

Temesközból jóval nagyobb számban ismertek a X. század második felére keltezhető temetó- és szórványleletek A Temesvár melletti Csóka-erdei temetőből 40 sírt, a hodonyi temetőből 18 sírt ismerünk, a Vejtétől néhány km-re fekvő csáki temetőrészből pedig 3 sírt. ${ }^{52}$ A temetők a X. század közepétól keltezhetők. Temesköz déli részén Dentáról oldalpálcás zabla mellékletes sír ismert (feldolgozása folyamatban).

A kutatás mai állapota alapján biztosan kijelenthetjük, hogy a X. század közepén a Temesközben magyar katonai közösségek telepedtek meg. VII. Bíborbanszületett Konsztantinosz császár (945-959) a magyarok szállásterületének, Turkiának nevezte a Temes-Béga(?)-MarosKörös és a Tisza vidékét. ${ }^{53} \mathrm{Az}$ ezredforduló táján Temesköz Ajtony uralmi területéhez tartozott. Valószínüleg a század második felére keltezett temetők Ajtony népének nyughelyei. Temetkezési szokásaik és anyagi kultúrájuk sajátosságai révén e temetők határozottan illeszkednek a Kárpát-medence más honfoglalás, és Árpád-kori temetőihez. A romániai régészetben hódító „besenyő-román" etnikumról szóló elméletek nem tû́nnek kellőképen megalapozottnak.

Érdekes és megoldandó feladat, mikor nyitották és mikor hagyták fel ezeket a temetőket. Helyben maradtak-e ezek a közösségek, vagy elsöpörte a Bánságot a magyar királyságba integráló folyamat a XI. század elején?

A Temesköz délnyugati részén elhelyezkedő Vejtén feltárt temetőrészlet e kérdés megválaszolásához nem tud megfelelő adatokat szolgáltatni. Biztos, hogy a X. század első felében Vejte határában temetőt nyitottak, de a temető felhagyása időpontjának megállapításához további kutatás szükséges.

50 Feltehetően korai lelet az oroszlámosi tárgyak egy része is (gömbsorcsüngős fülbevalók, lemez karperecek), a keglevicaházi övveretek, a Bukova-pusztai halomsírok, a németkomlósi és orsovai övveretek: BóNA 1988, 212-213; KovÁCS 1991-92, 51-53; TANASE-GÁLL 2001, s.a.

51 HAMPEL 1905, II. 560-564, 653-654.

52 Drasovean-Teicu-Muntean 1996, 34-43; Radu 1972, 61-63.

53 Váczy Péter szerint Turkia a gyula szállásterületét jelentette, Györffy György a gyula határvonalának a Marost tekintette, ezt a tételt kétségbe vonta Kristó Gyula (DÁvID 1974, 12, GYÖRFFY 1977, 47,163; KRISTÓ 1980, 451-452; MORAVCSIK 1984, 48). 


\section{IRODALOM}

BÁLINT, Cs.

1969 A honfoglalás kori lovastemetkezés néhány kérdése (Über die Pferdebestattungen der Landnahmezeit). MFMÉ 107-114.

1971a A honfoglalás kori lovastemetkezések (Les tombes a ensevelissement de chaval chez les hongrois de IXe-XIe siecles). MFMÉ 85-108.

1971b X. századi temető a szabadkigyósi-pálligeti táblában (Tenth century cemetery in the Pálliget plot of Szabadkígyós). BMMK 1, 49-88.

Bejan, A.-MARE, M.

1977 Dudestii Vechi-Pusta Bucova. Necropola si morminte de inhumatie din secolele VI-XII. Analelele Banatului 5, 139-158.

Bejan, A.-Moga, M.

1979 Necropola feudal-timpurie de la Hodoni (jud. Timis). Tibiscus V, 159-168.

BÓNA, I.

1986 A honfoglaló magyarok az Erdélyi medencében. In: Erdély története. Főszerk.: KöPECZI B., Szerk.: MAKKAY L.-MócsY A. Budapest, 194-237.

DÁvID, K.

1974 Az Árpád-kori Csanád vármegye múvészeti topográfiája. MŰF 7, 10-48.

DÖRNER

1970 Recherches et fouilles archéologiques dans le département d'Arad (románul). MCA 9, 445-465.

Drasovean, F.-TEICU, D.-Muntean, M.

1996 Hodoni. Locuirile neolitice si necropola medieval timpurie. Resita.

FÉK = FEHÉR, G.-ÉRY, K.-KRALOVÁNSZKY, A.

1962 A Közép-Duna medence magyar honfoglalás és kora Árpád-kori sírleletei. RégTan II. Budapest.

GÁlL, E.

2000 Rituri si ritualuri funerare in Bazinul Transilvanean din secolul X a dascalecatorilor maghiari. Acta Siculica s.a.

GIESLER, J.

1979 Untersuchungen zur Chronologie der Bjelo-Brdo. (Ein Beitrag zur Archäologie des 10. Und 11. Jahrhunderts im Karpatenbecken. PZ 56, 3-181.

GYÖRFFY, GY.

1977 István király és müve. Budapest.

HAMPEL, J.

1905 Újabb tanulmányok a honfoglaláskor emlékeiről. Budapest.

HOREDT, K.

1966 Die Ansiedlung von Blandiana, rayon Orastie, am Ausgang des ersten Jahrtausends u.Z. Dacia 10, 261-289.

K. K.

1996 A honfoglaló magyarság. Kiállítási katalógus. Szerk.: FoDOR I. Budapest.

KISS, L.

1920-22 Eperjeskei honfoglalás kori temető. ArchÉrt 39, 42-55.

KovÁcs, L.

1984 A Hajdúböszörmény-Erdős tanyai honfogaló magyar sírlelet. Adatok az avar- és honfoglalás kori szaluk elterjedéséhez (Landnahmezeitliche ungarische Grabfund von Hajdúböszörmény-Erdős-tanya, Angaben zur Verbreitung der Hohlbeile in der Awaren- und Landnahmezeit). HOMÉ 5, 19-53.

1985 A tímári (Szabolcs-Szatmár) honfoglalás kori temetőmaradványok (Landnahmezeitliche Gräberfeldreste von Tímár, Szabolcs-Szatmár). ComArchHung 125-158.

1991-92 A Móra Ferenc Múzeum néhány régi honfoglalás kori leletanyagáról: Oroszlámos, Horgos, Majdán, Rábé (Csóka) [Zu einigen alten landnahme-Zeitlichen Fundmaterialien des Móra Ferenc Museums: Oroszlámos, Horgos, Majdán, Rábé (Csóka)]. MFMÉ 37-74.

KRISTÓ, GY.

1979 Levedi törzsszövetségtől Szent István koráig. Budapest.

KÜRTI, B.

1978-79 Honfoglalás kori magyar temető Szeged-Algyőn. (Előzetes beszámoló) (Ein ungarisches Gräberfeld aus der Landnahmezeit in Szeged-Algyő). MFMÉ 323-345.

MEGAY, G.

1961 Honfoglalás kori temető Miskolc északkeleti határán (Ein Gräberfeld in Miskolc aus der Zeit der Landnahme der Ungarn, nordöstlich von Miskolc). ArchÉrt 88, 100-108. 
MESTERHÁZY, K.

1990 Temetkezési rend az ártándi 10-11. századi temetőben (Bestattungsordnung im Gräberfeld von Ártánd aus dem 10-11. Jahrhundert). ArchÉrt 117, 50-57.

MORAVCSIK, GY.

1984 Az Árpád-kori magyar történet bizánci forrásai. Budapest.

NAGY, Á.

1966 Az Eger-szépassszonyvölgyi X. századi temető (Gräberfeld von Eger-Szépasszonyvölgy aus dem X. Jh.). EMÉ 69-100.

PinTeR, K. Z.-LuCA, S. A.

1995 Necropola medieval timpurie de la Orastie-Dealul Pemilor. Punctul X2/1992-93. Corviniana 17-44.

RADU, O.

1972 Descoperiri intamplatoare la Ciacova. Jud Timis. Tibiscus 2, 61-63.

RĂDUlESCU, A.-GÁLL, E.

2000 Ein landnahmezeitliches Gräberfeld in Temesvár (Timişoara)-Csóka Erdő (Romania). Acta ArchHung s.a.

RÉvÉSZ, L.

1986 Líra alakú csatok a Kárpát-medencében (Lyraförmige Schnallen im Karpatenbecken). HOMÉ 27, 513-541.

1995 A karosi honfogaláskori temetők. Régészeti adatok a Felső-Tisza vidék X. századi történetéhez (Die Gräberfelder von Karos aus der Landnahmezeit. Archäologische Angaben zur Geschichte des oberen Theißgebietes im 10. Jahrhundert). Miskolc.

1996 Honfoglalás kori női sír Békéscsaba Erzsébethelyen (Ein landnahmezeitliches Frauengrab in Békéscsaba-Erzsébethely). MFMÉ-Studia Archaeologica 3, 169-195.

STANOJEV, N.

1986 Nekropole X-XV. veka u Voivodinu. Novi Sad.

SZABÓ, J. GY.

1978-79 Árpád-kori telep és temetője Sarud határában. IV. A sírok relativ és abszolút kronológiája. A temető jel-

SZŐKE, B. lege (Arpadenzeitliche Siedlung und Friedhof in der Gemarkung von Sarud. IV.). EMÉ 16-17, 45-136.

1961 A honfoglaló és kora Árpád-kori magyarság régészeti emlékei. RégTan I.

\section{EIN LANDNAHMEZEITLICHES GRÄBERFELDDETAIL DES 10. JAHRHUNDERTS IN VEJTE (KOM. TEMES, RUMÄNIEN)}

\section{Florin MENDELEȚ-Daniela TĂNASE-ERVIN GÁLl}

In der Mitte der 1980er Jahre wurden 4,5 km von der Eisenbahnstation des zum südwestlichen Teil des Temesköz gehörenden Vejte (Vojteni) Gräber eines spätbronzezeitlichen Gräberfeldes entdeckt. Im Herbst 1986 begannen die archäologischen Untersuchungen mit Beteiligung der Archäologen F. Mendeleț und A. Rădulescu des Banater Museums von Temesvár (Timişoara). Auch die spätbronzezeitliche Siedlung wurde erforscht. Im Suchgraben I (Abb. 1) fand man sieben landnahmezeitliche Gräber, die die Objekte der bronzezeitlichen Siedlung durchschnitten (Abb. 2).

Die Gräber mögen zu einem Gräberfeld mit größerer Grabzahl gehört haben. Leider wurde die weitere Freilegung dieses wichtigen archäologischen Objektes aus finanziellen Gründen abgebrochen.

Gräber 1 und 2. Ohne Beigaben.

Grab 3 (Abb. 3-5). Männergrab. Beigaben: Teile eines Köchers: Riemenverteiler, viereckiges Eisenblech. Pfeilspitzen. Beinerne Bogengriff- und Endplatten, Gurtschnallen, eiserne Steigbügel, Eisentrense, Eisenschnalle.
Grab 4 (Abb. 6). Frauengrab. Beigaben: Haarnadelfragment, Silberhaaarring, Bronzearmring, Bronzefingerring, Glasperle.

Grab 5. Ohne Beigaben.

Grab 6 (Abb. 7). Männergrab. Beigaben: Bronzering, Pfeilspitze, Eisenschnalle, Trensefragment.

Grab 7. (Abb. 8). Kindergrab. Beigabe: Bronzeschelle.

Das Fundmaterial ist aufgrund der Tracht, Bewaffung und des Pferdegeschirrs ein organischer Teil des Fundmaterials der landnahmezeitlichen materiellen Kultur. Die gegenständige Hinterlassenschaft der Gräber des Gräberfelderteils ist zugleich ein Index der gesellschaftlichen und wirtschaftlichen Lage dieser Gemeinschaft. Das Material der gegenständlichen Hinterlassenschaft der Tracht ist Silber und vor allem Bronze, die allgemein das Hauptmaterial der Ziergegenstände der Tracht bei den Gemeinschaften bescheidenerer gesellschaftlicher Stellung ist: Haarringe, Haarnadel, Armringe, Fingerringe, Schellen. Es fehlen auch die typischen Beigaben der männlichen Glieder der landnehmenden Gemeinschaften nicht: Bogen, Köcher, Pfeilspitzen. Die 
als Symbol einer anderen Weltreligion zu verstehende Reiterbestattung, in beiden Fällen symbolisch, ist aus Grab 3 und 4 bekannt. Als Datierung des Gräberfeldteils ist aufgrund des Fundmaterials, und zwar der Armringe und Fingerringe mit rombischem Querschitt, die zweite Hälfte des 10. Jhs. zu bestimmen.

Ungeachtet dessen, daß das Gräberfeld von Vejte nur zum kleinen Teil freigelegt wurde, gibt es gute parallelen seiner Struktur aus dem Bereich Theiß-Maros-ArankaTemes-Béga. Gräberfelder des waffentragenden Gemeinvolkes sind von mehreren Stellen dieser Mikroregion bekannt. So kennen wir aus den bekannten großen Gräberfeldern des Gemeinvolkes von Deszk, Kiszombor und Temesvár im Maros-Theiß-Aranka Gebiet und Temesköz sind auf die waffentragende Schicht hinweisende Spuren auch an anderen Fundorten bekannt, so etwa die Bestattungen und Streufunde von Keglevica, Nagyősz, Zsombolya und Törökbecse.

Eine genauere Beobachtung der Struktur des Gräberfeldteiles von Vejte kann aber nur durch erneute Ausgrabungen verwirklicht werden.

Das heutige Forschungsstadium liefert keine Abgaben zur Fixierung der genauen Zeit einer ungarischen Besetzung des Temesköz. Die Gebiete nach Westen und Norden wurden aufgrund des archäologischen Materials von den landnehmenden Ungarn am Beginn des Jahrhunderts besetzt. Aus dem Gebiet zwischen Theiß, Maros und Aranka sind sehr frühe Funde bekannt. Besonders bedauerlich am Forschungszustand ist, daß wir in erster Linie nur von Streufunden Kenntnis haben.

Auch nach Südosten wurden prächtige Grabfunde der Landnahme in Nagyteremia und Nagyősz entdeckt, die in die erste Jahrhunderthälfte datiert werden können.

Im Temesköz sind in die zweite Jahrhunderthälfte $\mathrm{zu}$ datierende Gräberfelder- und Streufunde in weit größerer Zahl bekannt. Aus dem Waldgräberfeld von Csóka bei Temesvár sind etwa 40 Gräber bekannt, von
Hodony 18, von Csák 3 Gräber. Diese Bestattungsorte sind aufgrund der Beigaben in die Zeit nach der 10. Jahrhundertmitte datierbar. Im zum Südteil des Temesköz gehörenden Denta wurde erst 1971 ein innerhalb des 10. Jhs. nicht genauer datierbares Grab mit einer Trense mit Seitenstäben, Messer und Keramikbeigaben gefunden.

Der heutige Forschungszustand berechtigt also bereits zu der sicheren Feststellung, daß in der 10. Jahrhundertmitte im Temesköz ungarische Militärgemeinschaften stationiert und in diesen Gebieten angesiedelt waren. In der Jahrhundertmitte bezeichnete der in Byzanz residierende Kaiser Konstantinos VII, Porphyrogennetos (945-959) das Gebiet zwischen Temes, Béga, Maros und Körös sowie das Theißgebiet als Siedlungsgebiet der Ungarn, Turkia. Um die Jahrtausendwende gehörte das Temesköz zum Herrschafsgebiet von Ajtony. Wahrscheinlich stammen die in die zweite Jahrhunderthälfte datierten Gräberfelder von Ajtonys Bewaffnetenschicht. Mit ihrer Struktur, den Bestattungsbräuchen und den Spezifika ihrer Sachkultur gliedern sich diese Gräberfelder aber betont in die Reihe anderer Gräberfelder aus der Landnahme- und Arpadenzeit der Region des Karpatenbeckens ein. Die in der rumänischen Archäologie an Beteutung gewinnenden Theorien einer „petschenegisch-rumänischen” Ethnizität sehen wir, gerade aufgrund dieser Bestattungsbräuche, als nicht genügend begründet an.

Viel interessanter verspricht die bisher ungelöste Aufgabe zu sein, festzustellen, wann diese Gräberfelder genau eröffnet und wann sie aufgelassen wurden. Blieben diese Gemeinschaften nach der Besiegung Ajtonys an ihrem Ort oder vertrieb sie die Integrierung des Banats ins ungarische Königsreich am Anfang des 11. Jahrhunderts? Eine Antwort auf diese Frage können nur erneute und viele umfangreichere Forschungen geben. 